\title{
Szerencsejáték és bünözés kapcsolatának magyarországi vizsgálata
}

\author{
TESSÉNYI JUDIT \\ kutató \\ E-mail: tessenyijudit@gmail.com \\ FARKAS GERGELY \\ egyetemi tanársegéd, Szegedi Tudományegyetem GTK, Üzleti Tudományok Intézete \\ E-mail:farkas.gergely@eco.u-szeged.hu
}

\begin{abstract}
Kutatásunkban a bűnözés és a szerencsejáték-függőség kapcsolatát, 175 fogvatartott börtönbe vonulás előtti játékszokásait, demográfiai jellemzőit és ezek kapcsolatait vizsgáltuk kérdőíves módszerrel. Ezt a kérdőívet használtuk már két korábbi, 2009-es és 2014-es kutatásunk során is, amelyek adatfelvételeken alapulva mérik fel az aktuális helyzetet. A kóros játékszenvedély vizsgálatára az South Oaks Gambling Screen (SOGS) kérdőív eredeti változatát alkalmaztuk, azt kiegészítve demográfiai, valamint a vizsgálatunk szempontjából releváns kérdésekkel. Bár a több mint tíz évet felölelö kutatásunk során a problémás szerencsejátékosok aránya csökkent a vizsgált magyar büntetés-végrehajtási intézetekben, még így is igen jelentősnek mondható. Vizsgálatunk során megerősítést nyert, hogy a büncselekmény elkövetésének közvetlen vagy közvetett oka a szenvedélyes szerencsejáték. A játékfüggők feminizációja egy viszonylag frissen kimutatott jelenség, melyre szintén kitérünk vizsgálatunk során. Emellett az intézményi dolgozók felkészítésére, képzésére és a veszélyeztetett kategóriában lévőkre is szeretnénk felhívni a figyelmet. Míg a vizsgáltak 11\%-a állította, hogy börtönbe kerülésének köze volt a szerencsejátékhoz, ez az arány a játékfüggők esetén $28 \%$ volt.
\end{abstract}

Journal of Economic Literature (JEL) kód: I12, K14

Kulcsszavak: szerencsejáték, függőség, játékszenvedély, börtön, SOGS

\section{Bevezetés}

Aktualitást ad vizsgálatunknak, hogy 2012. október 10-ével Magyarországon a játékgépek müködtetése a kaszinókra korlátozódott, így a szerencsejátékkal kapcsolatos függőségi problémák egy jelentős tényezője került ki a piacról. Ennek az eseménynek mérhető hatása 2015-ben még nem volt egyértelmü. Ezzel szemben 
az online szerencsejátékok piaca bővült, a hozzáférés egyre könnyebb a játékosok számára. A magyar lakosság körében - elsősorban a játékszervező Szerencsejáték Zrt. megbízásából - szinte évente kerül sor a játékszenvedély előfordulási gyakoriságának mérésére, viszont speciális veszélyeztetett társadalmi rétegekben alig. Jelenlegi vizsgálatunk a fogvatartottakra irányul, de hasonlóképp érdemes lenne vizsgálni a fiatalkorúakat és a szociálisan hátrányos helyzetűeket is.

Kérdöívünkkel felmértük, hogy a vizsgált fogvatartottak körében milyen arányban találunk szerencsejáték-függőket, hogy körükben milyen gyakori a betegségtudat. Az elemzés során kitértünk a szerencsejáték-függőség és a demográfiai tényezők kapcsolatára, továbbá arra, hogy a szerencsejáték-függőség milyen kapcsolatban áll a megjátszott összeg nagyságával, az ehhez szükséges pénzforrások előteremtésével, a játszott szerencsejáték típusával és a bűnelkövetéssel. Ezt követően a 2009-es és 2014-es adatokat és eredményeket összevetettük friss kutatásunk eredményeivel. Várakozásunk szerint az eltelt 5 évben is nőtt a függők és a veszélyeztetettek aránya, valamint a játék-automaták megszüntetése csak más játéktípus felé terelte a játszani vágyókat. Feltételezésünket arra alapozzuk, hogy ezen időszak alatt nagyon dinamikusan nőtt a szerencsejáték értékesítés Magyarországon (lásd Szerencsejáték Zrt. üzleti jelentései), különösen a magas addiktív potenciálú játékok forgalma emelkedett dinamikusan (pl. Tippmix).

A vizsgált időszakban az előzetes letartóztatásban lévők száma csökkent, míg az elítélteké és az elzárásra beutaltaké együttesen 3277 fővel nőtt. Összességében a tíz év alatt 10,9\%-os növekedés mérhető. A büntetés-végrehajtási intézetek típusát tekintve a fegyházakban és a börtönökben nőtt a fogvatartottak száma a vizsgált időszakban (1. számú táblázat), melynek okait nem vizsgáljuk.

Számos korábbi börtönkutatás világított rá, hogy a problémás vagy kóros szerencsejátékosok aránya a börtönökben nagyon változó, mindazonáltal ezeknek a csoportoknak az aránya következetesen és szignifikánsan magasabb, mint a lakosság körében regisztráltaké. Banks és szerzőtársai (2019) munkájukban 12 játékszenvedélyre vonatkozó, börtönökben végzett kutatás eredményét tanulmányozták át, melyből három fontos elemet szeretnénk kiemelni. Először is az általuk vizsgált tanulmányok kétharmada a SOGS mérési eszközt alkalmazta. Bár számos kutató kritika érte a SOGS-t az évek alatt, mégsem tudunk másik ilyen egyértelmű itemeket tartalmazó, könnyen használható és elfogadott eszközről. Összegzéséből látható, hogy a későbbi munkák már inkább a Problem Gambling Severity Indexre (PGSI) vagy az EIGHT Gambling Screenre támaszkodnak. Másrészt a közel 4000 fogvatartottra kiterjedő vizsgálatok közül csupán négy tartalmazott nemenként is elkülönített adatokat, amiknek korábbi vizsgálataink szerint jelentősége van. Harmadrészt a kutatásokban az itemek száma és a játékosok besorolása is gyakran változik, ezért a kutatások összehasonlítása során óvatosnak kell lenni (Banks et al. 2019).
1. számú táblázat: A büntetés-végrehajtási intézetben lévő elítéltek száma a büntetés-végrehajtási intézet típusa (büntetés-végrehajtási fokozat) szerint, 2008-2018

\begin{tabular}{|c|c|c|c|c|c|c|}
\hline Év & Fegyház & Börtön & Fogház & $\begin{array}{c}\text { Fiatalkorúak } \\
\text { börtöne }\end{array}$ & $\begin{array}{c}\text { Fiatalkorúak } \\
\text { fogháza }\end{array}$ & Összesen \\
\hline 2008 & 2,900 & 5,728 & 1,121 & 170 & 153 & 10,072 \\
\hline 2009 & 2,846 & 6,113 & 1,313 & 177 & 141 & 10,590 \\
\hline 2010 & 2,866 & 6,655 & 1,360 & 191 & 169 & 11,241 \\
\hline 2011 & 3,130 & 7,033 & 1,510 & 200 & 155 & 12,028 \\
\hline 2012 & 3,453 & 6,970 & 1,240 & 179 & 139 & 11,981 \\
\hline 2013 & 3,572 & 7,296 & 1,223 & 171 & 129 & 12,391 \\
\hline 2014 & 3,869 & 7,663 & 1,310 & 162 & 139 & 13,143 \\
\hline 2015 & 3,869 & 7,741 & 1,403 & 243 & 113 & 13,369 \\
\hline 2016 & 4,446 & 7,742 & 1,172 & 114 & 91 & 13,565 \\
\hline 2017 & 4,710 & 7,325 & 1,190 & 96 & 69 & 13,390 \\
\hline 2018 & 4727 & 7052 & 1103 & 105 & 51 & 13,038 \\
\hline
\end{tabular}

Megjegyzés: Börtönstatisztikai Szemle 2015-2019 számai alapján, saját szerkesztés

Japánban is végeztek hasonló kutatást (Yokotani et al. 2019), SOGS kérdőív alkalmazásával, ahol 38,55\%-nyi problémás játékost találtak a vizsgált 332 fogvatartott férfi körében, mely arány némiképp magasabb, mint a Banks és társai (2019) által összegyüjtött azonos módszertanú vizsgálatok elemszámra súlyozott átlaga, ami $22,85 \%$. A prevalencia mérésén túl arra is rámutattak, hogy fogvatartottak szerencsejáték iránti vágya a vagyon elleni büncselekményekkel korrelált, a drogokkal összefüggő és erőszakos büncselekményekkel azonban nem. A szerencsejáték iránti vágyuk kiélése során tehát inkább eszközként tekinthettek a bünözésre, de a fennálló állapot nem vezetett közvetlenül további függőségekhez vagy indulat bűnözéshez. Finnország két börtönében vizsgáltak (Lind et al. 2019) 97 fogvatartottat, ahol csak 16,3\%-ot azonosítottak függőként a Brios Biosocial Gambling Screen (BBGS) segítségével, de őket is az esetek harmadában vagyon elleni bűncselekmények miatt ítélték el.

Castrén, Heiskanen és Salonen (2018) hívták fel a figyelmet a szerencsejátékok feminizációjára annak kapcsán, hogy 2007-ben, 2010-ben és 2015-ben is felmérték Finnországban az aktuális játékszokásokat és azok alakulását keresztmetszet népességi felmérésekben. Eredményeik azt mutatják, hogy bár a szerencsejátékok még mindig fontosabb a férfiak számára, de a nők szerencsejátékokban való részvétele és a problémás szerencsejátékos nők száma a közelmúltban növekedett. A problémás szerencsejátékosokat kezelő finn intézetek megfigyelései azt mutatják, 
hogy egy új, fiatalabb nőkből álló csoport alakult ki, akiknek súlyos szerencsejáték-problémái vannak. A szerencsejátékok feminizációja tehát szerintük elsősorban életkor kérdése (Castrén-Heiskanen-Salonen 2018). A szerencsejátékokban való részvétel összességében növekvő tendenciát mutatott (6,6 százalékpont, 95\% CI 4,9-8,3) 2007 és 2015 között az általuk vizsgáltak körében. A 2007-2011-es időszakban a női szerencsejátékosok aránya nagyobb mértékben $(7,8$ százalékpont, 95\% CI 5,5-10,4) nőtt, mint a férfiaké (5,4 százalékpont, 95\% Cl 3,2-7,6) 2007 óta a legnépszerübb játéktípusok a lottójátékok, a kaparós sorjegyek és az elektronikus játékgépek (EGM-ek) voltak. Egy másik finn vizsgálat pedig a börtönőrök interjúin alapult, mely során két börtönben foglalkoztatott dolgozóinak ismereteit, nézeteit és véleményeit vizsgálták a problémás szerencsejátékokról a képzés javítása, a szerencsejáték-problémák azonosítása és az azokra való reagálás jobb iránymutatásainak kidolgozása céljából. A börtönben dolgozók négyötöde a szerencsejáték-problémát súlyos kérdésnek tekintette Finnországban. Az elmúlt évben tízből kilenc találkozott problémás szerencsejátékos fogvatartottal. A szerencsejáték-problémákat a fogvatartottak illegális tevékenységéről, pénzügyi helyzetről vagy egyéb problémákról folytatott beszélgetések során azonosították. A résztvevők csaknem fele úgy érezte, hogy nem rendelkezik megfelelő képzéssel vagy információval a szerencsejáték-problémákról és a kapcsolódó kérdésekről továbbá érdeklődést mutattak a továbbképzés iránt (Castrén et al. 2019).

\section{Módszertan}

Vizsgálatunk adatfelvételét 2019. októberében végeztük Kecskemét, Szeged, Eger és Gyula büntetés-végrehajtási intézeteiben. A korábbi, 2014-es adatfelvételre Sándorháza, Mélykút és Baracska büntetés-végrehajtási intézeteiben került sor, míg 2009-ben Tökölön, Kecskeméten és Szegeden vettünk fel adatokat.

Öt és tíz évvel ezelőtti vizsgálatunk során is a SOGS eredeti változatát használtuk (Leisure, Blume 1987) és a kiegészítő kérdések is ugyanebben a sorrendben és tartalommal kerültek bele a kérdöívbe. Ezek a kiegészítések - a demográfiai paraméterek mellett - a fogvatartás okaira, a családban előforduló esetleges függőségi problémákra, saját függőségének esetleges meglétére és játékszokásaikra vonatkoznak.

174 fogvatartott töltötte ki a kérdőívünket, amiből 167 volt értékelhető. A kitöltetés kiscsoportokban, önkéntes alapon történt, mely során 53 (31,7\%) női és 114 (68.3\%) férfi fogvatartott adott választ. Minden esetben kérdezőbiztosok segítették az értelmezést, mivel csoportonként átlagosan 1-1 főnek volt olvasási, értelmezési nehézsége. ${ }^{1}$ Azokat a kérdőíveket, melyek mégis hiányosan kerültek

Ezúton mondunk köszönetet kérdezőbiztosainknak: Fehér Attilának, Suha Tamásnak és Varga Noéminek. kitöltésre, kizártuk az elemzésből, ha a SOGS kérdések nem kerültek megválaszolásra vagy egyéb olyan ellentmondást találtunk, mely megkérdőjelezi a válaszok valódiságát (például soha nem játszott még életében, de besorolása alapján függő, vagy eldöntendő kérdésre minden válaszlehetőséget bejelölt). Viszont ha csak néhány kevéssé releváns választ hagyott ki, megtartottuk az adatait.

\section{Eredmények}

A válaszadók 27\%-a 30 év alatti és csupán 4\%-a nyugdíjas korú (2. táblázat). Iskolai végzettségüket tekintve felülreprezentáltak az alacsony végzettségűek. A kor esetén a megjelölhető kategóriák nem azonos hosszúságúak, de annyi leolvasható az első táblázatról a függőkre vonatkozóan, hogy a fiatal felnőttek és a középkorúak esetén is nagyjából 35\% a függők aránya a mintában, majd a 40 év felettieknél ez csökken. Ebben a korcsoportban a függők hiányának az alacsony mintaelemszám lehet az oka. Az iskolai végzettségre vonatkozóan a vizsgált fogvatartottak körében a teljes népességhez képest gyakoribb az alacsonyabb végzettség, de a függőség csak a diplomások körében alacsonyabb. Ennek értelmezésénél is érdemes azonban figyelembe venni az alacsony elemszámot. Számos korábbi vizsgálat igazolta, hogy a szerencsejátékosok attitüdje életkorfüggő, továbbá nemenként is eltérő (Salonen et al. 2017, McCarthy et al. 2018, Sharma et al. 2019).

\section{2. táblázat: a válaszadók demográfiai összetétele korcsoportok} és végzettség szerint $(\mathrm{N}=167)$

\begin{tabular}{|c|c|c|c|c|c|c|c|c|c|}
\hline Életkor & fö & \% & függö & $\%$ & Iskolai végzettség & fö & $\%$ & függö & $\%$ \\
\hline $18-30$ év & 45 & 26,9 & 16 & 35,56 & általános iskola & 63 & 37,7 & 17 & 26,98 \\
\hline $31-35$ év & 16 & 9,6 & 1 & 6,25 & szakmunkásképzö & 58 & 34,7 & 16 & 27,59 \\
\hline $36-40$ év & 34 & 20,4 & 10 & 29,41 & érettségi & 33 & 19,8 & 9 & 27,27 \\
\hline $41-62$ év & 63 & 37,7 & 15 & 23,81 & diploma & 12 & 7,2 & 1 & 8,33 \\
\hline 63 vagy idösebb & 6 & 3,6 & 0 & 0 & ismeretlen & 1 & 0,6 & & \\
\hline ismeretlen & 3 & 1,8 & & & & & & & \\
\hline
\end{tabular}

Forrás: saját szerkesztés

Az alábbi kereszttábla-elemzésünk (3. táblázat) a nemek szerinti eltérést vizsgálja, a SOGS besorolás viszonylatában. A korábbi vizsgálatok a nők körében alacsonyabb játékfüggőségi és magasabb veszélyeztetési előfordulást mértek a férfiakhoz képest (Hing et al. 2016) vagy éppen hasonló, de más mintázatú előfordulást (Hing-Nuske-Breen 2017). Az 53 női válaszadó mindössze 18,9\%-át találtuk 
függőnek, ugyanakkor nem volt szerencsejátékos problémája a megkérdezett nők 54,7\%-nak. Ezzel szemben a férfiak körében 28,9\% függőnek tekinthetö, és a veszélyeztetett kategóriába is nagyobb részarányban kerültek férfiak. A nemek közötti különbségekre a kultúra jelentős hatással lehet, ahogyan az a korábban ismertetett kutatásokból is látható. Eredményeink szerint bár a nők között tíz százalékponttal kevesebb a függő, de még ez sem elegendő különbség ahhoz, hogy az eredmény statisztikailag jelentősnek legyen mondható (khí=4,04; $\mathrm{p}=0.11$ ).

McCarthy és társai (2018) fentebb hivatkozott tanulmánya szerint, míg a nők az összes szerencsejátékot károsnak ítélték meg, addig a fiatalabb nök és a szerencsejátékosok (különösen az alacsony és közepes kockázatú csoportokban) kevésbé érzékelték egyes szerencsejáték-termékekkel (ló- és sportfogadások) kapcsolatos károkat, mint a idősebb nők és azok, akik nem szerencsejátékosok. Ez felvethet a kérdést, hogy a nők miért érzékelik kevésbé a szerencsejátékkal járó károkat. Mivel a nem szerencsejátékosok a szerencsejáték-termékeket károsabbnak tekintették, feltételezték, hogy a káros észlelés befolyásolja a szerencsejáték-termékek iránti elköteleződést. Megállapították, hogy összefüggés lehet a fiatalabb nők által a szerencsejátékokkal kapcsolatos felfogás és a szerencsejáték-termékek gyakori használata között. Ambrose és szerzőtársai dohányzással és az elektronikus cigaretta használatával kapcsolatban végzett kutatásai kimutatták, hogy minél inkább ártalmas az egyén észlelése egy termékről, és minél inkább érzékelik, hogy személyes veszélynek vannak kitéve, annál kevésbé valószínű, hogy megkezdik az adott termék használatát (Ambrose et al. 2014).

\section{3. táblázat: A válaszadók összetétele nemek és függőségi} besorolásuk szerint $(\mathrm{N}=167$ fó)

\begin{tabular}{|l|c|c|c|c|c|c|}
\hline \multirow{2}{*}{ Válaszadó neme } & \multicolumn{6}{|c|}{ SOGS kategória } \\
\cline { 2 - 8 } & \multicolumn{2}{|c|}{ nem problémás } & \multicolumn{2}{|c|}{ veszélyeztetett } & \multicolumn{2}{c|}{ függő } \\
\cline { 2 - 8 } & fö & $\%$ & fö & $\%$ & fö & $\%$ \\
\hline Férfi & 43 & 37,70 & 38 & 33,30 & 33 & 28,90 \\
\hline Nő & 29 & 54,70 & 14 & 26,40 & 10 & 18,90 \\
\hline Összesen & 72 & 43,11 & 52 & 31,14 & 43 & 25,75 \\
\hline
\end{tabular}

Forrás: saját szerkesztés

Tíz évvel ezelőtt a vizsgált 150 fogvatartottnak csupán 33\%-áról állíthattuk, hogy nincs problémája a szerencsejátékkal, és $30 \%$ a veszélyeztetett kategóriába került (4. táblázat). Mostani vizsgálatunk $43 \%$ esetén talált problémamentességet, ami újabb közel 5 százalékpontot csökkent 2014 óta. A legnagyobb változás a függők körében van, ahol a 2014 -es $40 \%$ visszaesett $25 \%$ közelébe.
4. táblázat: A magyar börtön SOGS vizsgálatok eredményei 2009-2019 (\%)

\begin{tabular}{|l|c|c|c|}
\hline & 2009 & 2014 & 2019 \\
\hline nem problémás & 32,9 & 33,6 & 43,1 \\
\hline veszélyeztetett & 30,7 & 25,7 & 31.1 \\
\hline függö, problémás játékos & 36,4 & 40,7 & 25,8 \\
\hline
\end{tabular}

Forrás: saját szerkesztés

A Szerencsejáték Zrt. 2018-as Magyarországon mért eredményei szerint a PGSI kritériumai alapján bár a 2009-es 1,2\%-ról 2018-ra 4,3\%-ra nőtt a játékfüggők aránya, de ez hibahatáron belüli változást jelent. Ez alapján kijelenthetjük, hogy a fogvatartottak körében a szerencsejáték függőség előfordulása jelentősen magasabb, mint normál populációban. Ugyanez a többi addiktológiai probléma (alkohol, drog) esetén is megállapítható (5. táblázat).

Calado és Griffith számos európai kutatási eredmény másodelemzésével megállapították, hogy a problémás szerencsejáték-előfordulása az egész világon 0,12\% és 5,8\% közötti, a legmagasabb arány Hongkongban volt. Az európai problémás szerencsejáték-elöfordulás aránya pedig $0,12 \%$ és 3,4\% között változott a regionális felmérések alapján (Calado és Griffith 2016). Az európai szerencsejáték-tendenciákat vizsgálva megjegyezték, hogy a problémás szerencsejáték-arányok sok országban stabilak maradtak, ahol több szerencsejáték-felmérést is végeztek (például Nagy-Britannia, Hollandia, Németország), más országokban viszont, például Észtországban, megnőtt a problémás szerencsejáték-előfordulási arány.

\section{5. táblázat: Szenvedélybetegség kérdésére adott válaszok (\%)}

\begin{tabular}{|c|c|c|c|c|c|}
\hline év & alkohol & drog & alkohol és drog is & szerencsejáték & egyéb \\
\hline 2009 & 12,85 & 19,3 & 5,71 & 12,14 & 12,1 \\
\hline 2014 & 12,85 & 21,4 & 4,28 & 9,28 & 10,7 \\
\hline 2019 & 10,2 & 22,2 & 4,9 & 16,2 & 18,4 \\
\hline
\end{tabular}

Forrás: saját szerkesztés

Az előző két kutatásban is feltettük a kérdést, hogy véleménye szerint „a büntetendő cselekmény elkövetésében szerepet játszott-e a szerencsejáték?" 10,8\% válaszolt most is igennel, míg 2014-ben 12,14\%, ami a lehetséges torzításokat figyelembe véve nem tekinthető jelentős eltérésnek. 
A SOGS kérdéseire adott válaszokból a leggyakrabban a többlet költést (többet játszott annál, mint eredetileg szándékozott) jelölték meg (40\%) és a büntuda (érzett már bűntudatot szerencsejátékozása vagy a játék következményei miatt) is gyakori válasz volt (35\%) a veszélyeztetetteknél. A függők esetében a többlet költés (93\%) mellett az a válasz emelkedett ki, hogy viselkedésüket maguk is problémának érezték (86\%).

Az alábbi (1. számú) ábrán követhető, hogy a függők esetében szisztematikusan magasabb a nagyobb összegű költések aránya, míg a veszélyeztetetteknél ez viszonylag egyenletesen oszlik el a különböző tétek között. A nem problémás játékosok 68\%-a egyáltalán nem vagy 1000 forint alatt játszott. A 100 forint vagy annál kisebb válaszlehetőség megbízhatóságát csökkenti, hogy jelenleg szinte kizárt, hogy valaki legális módon ilyen értékben játsszon, mert a hivatalosan megvásárolható játéklehetőségek ennél drágábbak.

\section{1. ábra: Játékosok száma az egyes SOGS kategóriákban} a legmagasabb megjátszott összeg szerint

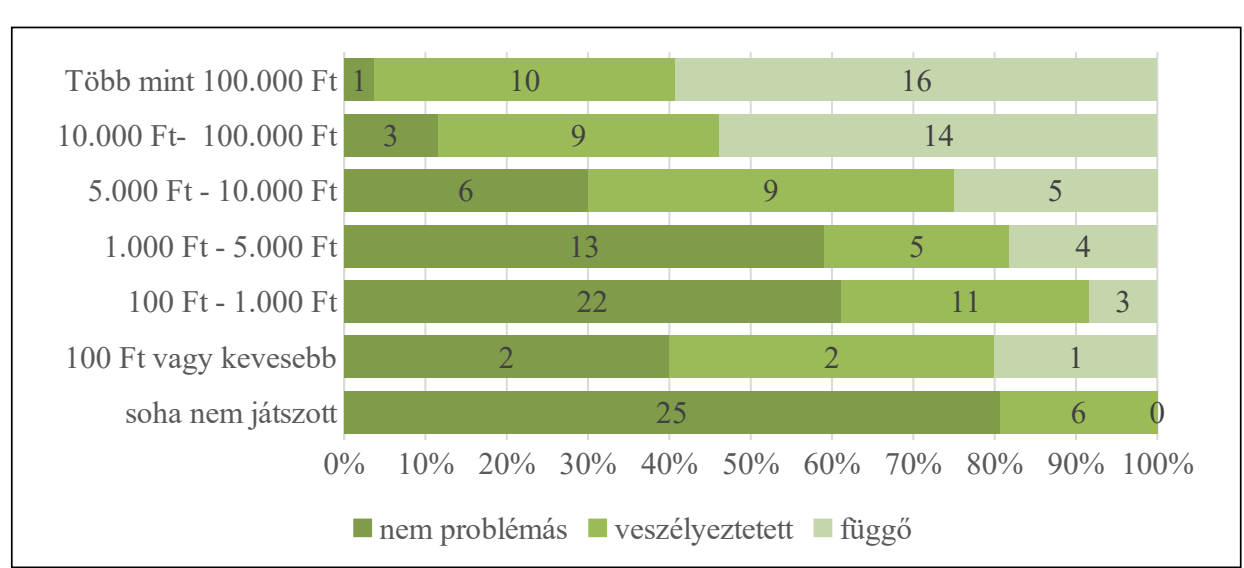

Forrás: saját szerkesztés

A releváns költési kategóriákat a korábbi évek eredményeivel összehasonlítva az látható, hogy bár kisebb arányeltolódások felfedezhetők, de a költések U-alakú mintázata megmaradt, tehát gyakoribb a kisebb értékü, a függőknél valószínűleg napi rendszerességü költés. Emellett pedig a nagyobb, tízezer forint feletti maximumok. Utóbbi esetekben már havi néhány játéknap is elég lehet, hogy a játékos, vagy akár annak családja életét is befolyásolja a szerencsejáték egy átlagosnak tekinthető jövedelemszint mellett.
6. táblázat: Megjátszott összegek és adott kategórián belüli függők száma és annak változása (2009-2014-2019.)

\begin{tabular}{|l|c|c|c|c|c|c|}
\hline $\begin{array}{l}\text { megjátszott összeg } \\
\text { maximuma (Ft) }\end{array}$ & $\begin{array}{c}2009 \\
(\%)\end{array}$ & $\begin{array}{c}\text { ebböl függő } \\
\text { (fö) }\end{array}$ & $\begin{array}{c}2014 \\
(\%)\end{array}$ & $\begin{array}{c}\text { ebböl függő } \\
\text { (fö) }\end{array}$ & $\begin{array}{c}2019 \\
(\%)\end{array}$ & $\begin{array}{c}\text { ebből függö } \\
\text { (fö) }\end{array}$ \\
\hline $100-999$ & 18,1 & 0 & 22,9 & 6 & 21,6 & 3 \\
\hline $1000-4999$ & 11,6 & 4 & 14,3 & 7 & 13,2 & 4 \\
\hline $5000-9999$ & 17,4 & 9 & 11,4 & 9 & 12,0 & 5 \\
\hline $10000-100000$ & 13,8 & 15 & 17,1 & 7 & 15,6 & 14 \\
\hline 100.000 felett & 23,9 & 22 & 16,4 & 17 & 16,2 & 16 \\
\hline
\end{tabular}

Forrás: saját szerkesztés

A függők esetében valamennyi szerencsejáték-típus sokkal népszerűbb, de még mindig a játékgépek vezetik a rangsort, mely után közvetlen a sorsjegyesek is felzárkóztak. A veszélyeztetettek esetében is az látszik, hogy érdeklődésük szélesebb, többféle játékot kipróbálnak. A játékgépek visszaszorulása ellenére még mindig ez az a játéktípus, ami a nem problémásakat hidegen hagyja, de a veszélyeztetetteknél már dobogós helyen szerepel. Vannak a játéktípusok között nemi különbségek is, mivel a férfiaknál a játékgép és a sorsjegy a legkedveltebb, de a nőknél a játékgép csak a középmezőnyben van. A sorsjegy mellett ők a lottójátékot kedvelik.

2014-es vizsgálatunk során a játékfüggők a pénzügyi lehetőségeik csökkenésekor leggyakrabban a háztartásból és ingóságaik eladásából szereztek pótlólagos pénzforrást a játékukhoz, jelen kutatásunk során is megvizsgáltuk, hogy a függó kategóriába került játékosok milyen eszközhöz nyúlnak leginkább, ha elapadt a játékra költhető keret. A nem problémás játékosoknál nem fordult elő, hogy pótlólagos pénzszerzésre lett volna szükségük. Ez egy olyan fontos jel lehet, ami a környezet figyelmét egyértelműen felhívhatja, hogy a játékszenvedély problémájával foglalkozni kell. A 7. táblázatban látható, hogy míg a veszélyeztetettek in kább a „családi kasszába nyúlnak bele” addig a függők a távolabbi kapcsolatok felé fordulnak, és kiemelkedik az ingóságok eladása, ahogy a korábbi kutatásokban is.

A megkérdezettek legtöbbje most is lopás miatt tölti szabadságvesztését, pedig ezek általában kisebb büntetési tétellel járnak. Az előző évek adataival az összehasonlítás nem kézenfekvő, hiszen nemcsak a válaszadók, hanem a vizsgált intézmények is változtak, és köztudomású, hogy a büntetés-végrehajtás egyes intézményei eltérő profillal rendelkezhetnek ebben a tekintetben. Számunkra ezért inkább a függőséggel való kapcsolat azonosítása a fontos, ami szerint a Bonferroni korrekcióval végzett összehasonlítás alapján kiugró a függők körében rablás esetén. Ez azt jelenti, hogy míg a szerencsejáték szempontjából nem problémásaknak csak 8,6\%-a tölti rablás miatt a büntetését, addig a veszélyeztetettek körében már 14\%, 


\section{7. táblázat: Pótlólagos pénzszerzés módja a SOGS szerint} játékos kategóriákban

\begin{tabular}{|l|c|c|c|c|}
\hline \multicolumn{1}{|c|}{ Pótlólagos pénzszerzés módja } & \multicolumn{2}{|c|}{ veszélyeztetett } & \multicolumn{2}{c|}{ függö } \\
\hline háztartási pénzből & $\mathrm{N}$ & $\%$ & $\mathrm{~N}$ & $\%$ \\
\hline házastársától / partnerétől & 7 & $38.9 \%$ & 14 & $37.8 \%$ \\
\hline rokonoktól vagy apóstól, anyóstól & 5 & $27.8 \%$ & 18 & $48.6 \%$ \\
\hline banktól, hitelintézettől & 2 & $11.1 \%$ & 19 & $51.4 \%$ \\
\hline hitelkártyáról & 1 & $5.6 \%$ & 9 & $24.3 \%$ \\
\hline uzsorásoktól & 1 & $5.6 \%$ & 11 & $29.7 \%$ \\
\hline kötvényeket, értékpapírokat értékesített & 0 & $0.0 \%$ & 10 & $27.0 \%$ \\
\hline eladta személyes vagy családi tulajdonát & 1 & $5.6 \%$ & 2 & $5.4 \%$ \\
\hline nem létező fedezetet próbált felhasználni & 2 & $11.1 \%$ & 27 & $73.0 \%$ \\
\hline
\end{tabular}

Forrás: saját szerkesztés

a függőknél pedig 30,2\% ez az arány. Tehát feltételezhetjük az ok-okozati összefüggés valószínű irányát, hogy a játékszenvedély növeli annak valószínűségét, hogy a játékos akár erőszak árán is pénzhez akar jutni. Az „egyéb büncselekmény”-t megjelölők közül a nyitott választ 59 fö adott, ami alapján 19 főt, azaz a teljes minta 11,4\%-t gazdasági büncselekmények, főként csalás miatt ítélték el. A gazdasági büncselekményeknél nem találtunk összefüggést a függőséggel. Érdekes lehet viszont a további kutatások számára, hogy kábítószerrel kapcsolatban a függők esetén kevesebb esetet, míg életellenes büncselekmények elkövetői között többet találtunk, ami arra utalhat, hogy a szerencsejáték függőség az impulzuskontroll zavarával hozható összefüggésbe (Sharman et al. 2019).

8. táblázat: A vizsgált bünelkövetők főbb büncselekménycsoportok szerint

\begin{tabular}{|l|c|c|c|c|c|c|}
\hline & \multicolumn{2}{|c|}{2009} & \multicolumn{2}{c|}{2014} & \multicolumn{2}{|c|}{2019} \\
\hline büncselekmény & fö & $\%$ & fö & $\%$ & fö & $\%$ \\
\hline betörés & 13 & $7,8 \%$ & 12 & $7,3 \%$ & 11 & $6.70 \%$ \\
\hline testi sértés & 13 & $7,8 \%$ & 25 & $15,2 \%$ & 22 & $13.50 \%$ \\
\hline rablás & 30 & $18,0 \%$ & 45 & $27,4 \%$ & 26 & $16.00 \%$ \\
\hline lopás & 46 & $27,5 \%$ & 26 & $15,9 \%$ & 41 & $25.20 \%$ \\
\hline garázdaság & 18 & $10,8 \%$ & 9 & $5,5 \%$ & 17 & $10.40 \%$ \\
\hline egyéb & 47 & $28,1 \%$ & 47 & $28,7 \%$ & 87 & $53.40 \%$ \\
\hline
\end{tabular}

Forrás: saját szerkesztés
A bűnözéssel kapcsolatban rákérdeztünk továbbá, hogy visszaeső-e a válaszadó amire a válaszadók fele igennel felelt. A SOGS kategóriák alapján a függők esetén kimutathatóan több a visszaeső (khí=10.412, p=0,005). Ha azonban a nemek alapján is összevetjük az adatokat, akkor kiderül, hogy az összefüggés csak a férfiak esetén kimutatható, de nőknél nem szignifikáns (khí=4.565, p=0,102).

A kapcsolati hálóban a nem problémás játékosok leggyakrabban a baráti társaságban találkoztak más szerencsejáték függővel korábban. A függőnek besoroltak között viszont a testvér szerencsejáték függősége kimutathatóan gyakoribb az eloszlásban amellett, hogy a barátok, rokonok és az apa is többször fordult elö játékfüggőként a függők válaszaiban. Korábban, bármilyen függőséggel kapcsolatban a nem problémás és veszélyeztetett játékosok $30 \%$-a vett igénybe, míg a függőknél ez $45 \%$, de az eltérés nem szignifikáns. A korábbi munkaviszony vagy a gyermekvállalás voltak még olyan tényezők, amiket vizsgáltunk, de nem találtunk kapcsolatot a szerencsejáték-függőséggel.

\section{4. Összegzés}

Összességében az öt és tíz évvel ezelőtti mérési eredményekkel összevetve a 2019 es mérés eredményei alapján megállapíthatjuk, hogy néhány százalékpontot csökkent a szerencsejátékfüggőségi-probléma a vizsgált börtönpopulációban. Ennek azonban véleményünk szerint lényeges oka, hogy a jelenleg vizsgált mintában sokkal magasabb volt a nők aránya. A 2014-es mérésben még csak tíz válaszadó volt nő, 2019-ben már ötvenhárom. Az adatokból inkább arra következtetünk, hogy a szerencsejáték-függőség a férfi fogvatartottak életének kétharmadára, a női fogvatartottaknak felére hatással van. Azt a következtetést is levonhatjuk, hogy hazai kutatásokban a nemek közötti játékszokásokat és attitüdöt mindenképp külön érdemes vizsgálni. A kérdöívek kitöltetése során magunk is tapasztalhattuk, hogy a nők sokkal „fegyelmezetlenebbek” voltak, egymással beszélgettek, figyelték a mellettük ülő válaszait és közel dupla annyi időt vett igénybe a négy oldalas kérdőív kitöltése, mint a férfi fogvatartottak esetében. Nemi különbséget mutattunk ki a játéktípusokkal kapcsolatban is.

A bűnözéssel kapcsolatban a rablással találtunk kimutatható kapcsolatot a szerencsejáték-függőknél és a jövőben az életellenes bűncselekményekre is érdemes a kutatóknak nagyobb figyelmet fordítani, mert a nyitott válaszok alapján valószínűleg ott is van összefüggés. A kábítószerrel kapcsolatban a függőség néhány százalékponttal magasabb a szerencsejáték-függők körében, de statisztikailag nem jelentős az eltérés, és a kábítószerrel kapcsolatos bűncselekmények ritkábban okai fogvatartásuknak. Kiemelhető még, hogy többen jelölték magukat drogfüggőnek (43\%) a mintában, mint szerencsejáték-függőnek (31,4\%), de ennél még többen lehetnek érintettek. Az általunk vizsgált szerencsejáték-függőség esetén a SOGS 
kérdőív az esetek 56,4\%-ban jelzett legalább veszélyeztetettséget. A szerencsejáték-függőség tehát a fogvatartottak legalább felének hatással van az életére, amit érdemes figyelembe venni a társadalomi visszailleszkedésre való felkészülés során.

A szerencsejátékosok a korábbi vizsgálatokhoz hasonlóan a játékok árát elsősorban a háztartási pénzből, családtagoktól kapott pénzzel egészítik ki, majd a függőség erősödésével egyre szélesebb rokoni körhöz, pénzintézetekhez fordulnak. Függők esetében kiemelkedően gyakorivá válik a saját ingóságok értékesítéséből fedezett játék. Ha pedig ezek a lehetőségek is kimerülnek, akkor a függőség a bün útjára vezet. A nem problémás és veszélyeztetett játékosoknak csak 5-6\%-a hozta összefüggésbe a bűncselekményét szerencsejátékkal, de a függőknek már 28\%-a állította, hogy jelenlegi fogvatartásához köze van a szerencsejátéknak. Az előzetesen felállított kategóriák alapján ilyen büncselekmény tipikusan a rablás, de a nyitott válaszok elemzése alapján az életellenes bűncselekményekkel kapcsolatban is tényező lehet a szerencsejáték, amiért ezt a cselekménykört érdemes a későbbiekben tovább vizsgálni.

A szerencsejáték és a bünelkövetés összefonódásai nem meglepőek a hétköznapi és a szakirodalmi tapasztalatok alapján sem. A fogvatartottak körében végzett kutatásunk korlátozó tényezői közül a legjelentősebb, hogy az elítéltek elhelyezését számos tényező befolyásolja, miközben a vizsgálat helyszínét az adott évben kapott engedélyek alapján határoztuk meg, ahol az elítéltek csak önkéntes alapon voltak bevonhatók a vizsgálatba. Mindezen korlátok mellett is fontosnak tartjuk a felelős játékszervezés érdekében rávilágítani az ezen a területen zajló folyamatokra.

\section{Hivatkozások}

Ambrose, B. K. - Rostron, B. L. - Johnson, S. E. - Portnoy, D. B. - Apelberg, B J. - Kaufman, A. R. - Choiniere, C. J. (2014): Perceptions of the relative harm of cigarettes and e-cigarettes among US youth. American journal of preventive medicine, Vol. 47, No. 2:S53-S60. DOI: 10.1016/j.amepre.2014.04.016

Banks, J. - Waters, J. - Andersson, C. - Olive, V. (2019): Prevalence of gambling disorder among prisoners: a systematic review. International Journal of Offender Therapy and Comparative Criminology, online: 2019.07.17. DOI: $10.1177 / 0306624 \mathrm{X} 19862430$

BvOP (2015-2019) Börtönstatisztikai Szemle Budapest: Büntetés-végrajtás Országos Parancsnoksága (BvOP), Hivatal, Stratégiai, Elemzési és Tervezési Főosztály.

Castrén, S. - Heiskanen, M. - Salonen, A. H. (2018): Trends in gambling participation and gambling severity among Finnish men and women: cross-sectional population surveys in 2007, 2010 and 2015. BMJ Open, Vol. 8, No. 8:e022129. DOI: 10.1136/bmjopen-2018-022129

Castrén, S. - Lind, K - Järvinen-Tassopoulos, J. - Alho, H. - Salonen, A. H. (2019): How to Support Prison Workers' Perceived Readiness to Identify and Respond to Possible Gambling Problems: a Pilot Study from Two Finnish Prisons. International Journal of Mental Health and Addiction, online: 2019.04.23. DOI: $10.1007 /$ s11469-019-00083-4

Calado, F. - Griffith, M. D. (2016): Problem gambling worldwide: An update and systematic review of empirical research (2000-2015); Journal of Behavioral Addictions, Vol. 5, No. 4:592-613. DOI: 10.1556/2006.5.2016.073

Hing, N. - Russell, A. - Tolchard, B. - Nower, L. (2016): Risk factors for gambling problems: An analysis by gender. Journal of Gambling Studies, Vol. 32, No. 2:511-534. DOI: 10.1007/s10899-015-9548-8

Hing, N. - Nuske, E. - Breen, H. (2017): A Review of Research into Problem Gambling amongst Australian Women. in: Bowden-Jones, H., Prever, F Gambling Disorders in Women: an International Female Perspective. New York: Routledge. DOI: 10.4324/9781315627625-24

Kovács Péter - Tessényi Judit (2015): Viselkedési addikciók és játékszokások a fogvatartottak körében. Börtönügyi Szemle, Vol. 34, No. 69:56-69.

Lesieur, H. R. - Blume, S. B. (1987): The South Oaks Gambling Screen (SOGS): A new instrument for the identification of pathological gamblers. American Journal of Psychiatry, Vol. 144, No. 9:1184-1188. DOI: 10.1176/ajp.144.9.1184

Lind, K. - Salonen, A. - Järvinen-Tassopoulos, J. - Alho, H. - Castrén, S. (2019): Problem gambling and support preferences among Finnish prisoners: a pilot study in an adult correctional population. International Journal of Prisoner Health, Vol. 15, No. 4:316-331. DOI: 10.1108/IJPH-07-2018-0041

McCarthy, S. - Thomas, S. L. - Randle, M. - Bestman, A. - Pitt, H. - Cowlishaw, S. - Daube, M. (2018): Women's gambling behaviour, product preferences, and perceptions of product harm: differences by age and gambling risk status. Harm Reduction Journal, Vol. 15, No. 1:22. DOI: 10.1186/s12954-018-0227-9

Salonen, A. H. - Alho, H. - Castrén, S. (2017): Attitudes towards gambling, gambling participation, and gambling-related harm: cross-sectional Finnish population studies in 2011 and 2015. BMC Public Health, Vol. 17., Art. 122. DOI: 10.1186/s12889-017-4056-7

Sharma, M. K. - Rao, G. N. - Benegal, V. - Thennarasu, K. - Thomas, D. (2019) Behavioral addiction as a comorbidity to pathological gambling: Implication for screening and intervention in health setting. Indian Journal of Social Psychiatry, Vol. 35, No. 1:93-97. DOI: 10.4103/ijsp.ijsp_109_17

Sharman, S. - Clark, L. - Roberts, A. - Michalczuk, R. - Cocks, R. - Bowden-Jones, H. (2019): Heterogeneity in disordered gambling: decision-making and impulsivity in gamblers grouped by preferred form. Frontiers in psychiatry, Vol. 10, Art. 588. DOI: 10.3389/fpsyt.2019.00588 
Szerencsejáték Zrt. (2019): Szerencsejáték-függőségi információk 2018, http:// www.maradjonjatek.hu/szerencsejatek-fuggosegi-informaciok-2018, Letöltve: 2020. 01. 05.

Tessényi, Judit - Kovács Péter. (2011): Szerencsejáték-függőség és bűnözés. Statisztikai Szemle, Vol. 89, No. 4:399-419.

Tessényi Judit (2013): Játékszenvedély gazdaságpszichológiai megközelítésben. $\mathrm{PhD}$ értekezés, Szegedi Tudományegytem, Szeged.

Tessényi Judit, Kovács Péter (2015): Szerencsejáték és bünözés kapcsolatának vizsgálata. Ügyészek Lapja, Vol. 22, No. 1:29-37.

Yokotani, K. - Tamura, K. - Kaneko, Y. - Kamimura, E. (2019): Craving for Gambling Predicts Income-Generating Offenses: A Pathways Model of a Japanese Prison Population. Journal of gambling studies, online: 2019.08.24. DOI: 10.1007/s10899-019-09887-4 